\title{
Om at måle lærernes differentieringspraksis
}

\author{
Stefan Ting Graf, docent, UCL Erhvervsakademi og \\ Professionshøjskole, stgr@ucl.dk \\ Dorthe Carlsen, lektor, UC Syd, dcar@ucsyd.dk
}

\begin{abstract}
Résume
Kan man måle læreres differentieringspraksis, og i så fald hvordan? Hvad kan større kvantitative undersøgelser af læreres differentieringspraksis vise? Og hvorfor er spørgsmålet om operationalisering af differentieringsbegrebet interessant og vigtigt?

Ved at præsentere fire teoretiske forståelser af undervisningsdifferentiering udfordres den forestilling, at der kun findes ét differentieringsbegreb. På denne baggrund analyseres fem danske, kvantitative spørgeskemaundersøgelser af læreres differentieringspraksis med henblik på en sammenlignende opstilling. Det viser sig, at undersøgelserne måler forskellige ting, og at deres resultater ikke bare kan sammenlignes. Der er behov for en metodisk mere grundig tilgang til den slags målinger, som ofte har uddannelsespolitisk betydning. I kvantitative undersøgelser vedrører operationalisering af den afhængige variabel undersøgelsens validitet og afspejler samtidigt i høj grad et syn på, hvad didaktiske fænomener som undervisningsdifferentiering er eller bør være. Artiklens formål er at diskutere indholdsmæssige og metodiske problemstillinger for, hvordan man kan undersøge differentieringspraksisser på et pædagogisk og dannelsesteoretisk grundlag.
\end{abstract}

Nøgleord: undervisningsdifferentiering, kvantitativ evaluering, forskningsmetoder, spørgeskema, operationalisering

\begin{abstract}
Is it possible to measure teachers' differentiated instruction? What can quantitative studies of teachers' differentiated instruction show? And, why is the question of the operationalization of the concept interesting and important?

By a presentation of four theoretical strands of the concept, the article challenges the idea that there is only one unifying concept of differentiation. On the backdrop of this, five Danish, quantitative surveys of differentiated instruction are analyzed in order to compare their operationalizations. The analysis reveals an urge for rethinking the design of such quantitative studies. The operationalization of the dependent variable represents not only the validity of research designs but also expresses different views of and normative expectations towards the phenomenon in question. The purpose of the article is to discuss different methodological challenges of how it would be possible to study the practice of differentiation on a pedagogical foundation.
\end{abstract}

Keywords: differentiated instruction, quantitative evaluation, research methodology, survey, operationalization 


\section{Differentiering er ikke bare differentiering}

Der findes ikke kun forskellige teoretiske og praktiske forståelser af dette undervisningsprincip; men også empiriske undersøgelser tolker dette begreb på forskellige måder. I denne artikler ønsker vi at stille skarpt på kvantitativt-empiriske undersøgelser af undervisningsdifferentiering i de danske grundskoler. Der findes endnu ikke mange af denne type undersøgelser, men mange nok til, at der er behov for at se nærmere på disse. Sådanne undersøgelser eller evalueringer indeholder ikke kun en ganske bestemt tolkning af begrebet undervisningsdifferentiering, men har endvidere "konstitutive virkninger", dvs. de udøver en skabende indflydelse på virkeligheden (Dahler-Larsen, 2008b, s. 17). Peter Dahler-Larsen redegør for en række forskellige virkninger, undersøgelser og evalueringer kan have, fx politiske, strategiske, symbolske m.m. Det betyder, at såvel forskere, læreruddannere, myndigheder og skolens praktikere bør interessere sig for den slags kvantitative undersøgelser i det pædagogiske felt. Selvom den slags undersøgelser først og fremmest virker igennem, hvem der bruger resultaterne på hvilke måder og i hvilken kontekst, så har de alene i kraft af deres måling en kvalitetskonstituerende virkning. Det sker igennem den kvantitative undersøgelses operationalisering af begrebet undervisningsdifferentiering; operationaliseringen bliver en slags indikator for det pædagogiske fænomen. Det er imidlertid ikke sikkert, at operationaliseringen indfanger selve den didaktiske kvalitet $i$ at differentiere, men den kommer nemt til at fremstå som udtryk for kvalitet. Ifølge Dahler-Larsen sker det især ved mekanismen "indikatorfiksering", dvs. "når indikatoren begrebsligt set bliver definitionen på kvalitet" (Dahler-Larsen, 2008b, s. 18). Det sker, når diskussionen af, hvad god undervisningsdifferentiering er, erstattes af en målt og operationaliseret definition på differentiering. Når en spørgeskemaundersøgelse eller en evaluering af differentieret undervisning for eksempel konkluderer, at lærerne differentierer enten mere eller mindre, så rykker denne mere eller mindre-diskussion i centrum, mens spørgsmålet om kvalitet i differentieringspraksis glider i baggrunden. Endvidere bliver sådanne rapporters resultater i den offentlige debat typisk citeret, uden at de metodiske begrænsninger medtages (fx Danmarks Evalueringsinstitut, 2017).

\section{At operationalisere undervisningsdifferentiering}

I denne situation er der behov for et kritisk blik på kvantitative undersøgelser af læreres praksis med undervisningsdifferentiering. Vores dobbelte 
forskningsspørgsmål er derfor: Hvordan operationaliseres læreres undervisningsdifferentieringspraksis i udvalgte danske, kvantitative undersøgelser, og hvilke metodiske problemstillinger kan vi identificere med henblik på fremtidige undersøgelser af dette princip? Med vores studie ønsker vi således at bidrage til kritisk analyse af eksisterende operationaliseringer af differentieringsforståelser og -praksis og samtidig at tilvejebringe et bedre udgangspunkt for kommende målinger af dette didaktiske princip på et pædagogisk grundlag.

For at kunne svare herpå har vi for det første brug for en begrebsafklaring. Her støtter vi os til vores tidligere gennemførte analyse af danske publikationer om differentiering. For det andet undersøger vi de to mest fremtrædende evalueringer af undervisningsdifferentiering gennemført af Danmarks Evalueringsinstitut (Danmarks Evalueringsinstitut, 2004; 2011b). For det tredje diskuterer vi selvkritisk tre spørgeskemaundersøgelser, som vi selv på forskellig vis har været involveret i: Effektmåling i AUUC-konsortiets demonstrationsskoleforsøg (Pettersson et al., 2015), Esbjerg-undersøgelsen om folkeskolelæreres elevfeedback (Graf \& Carlsen, 2016) og en virkningsevaluering af digital projektdidaktik i de frie grundskoler (Agergaard et al., 2017c). Disse undersøgelser er vores primære analyseobjekt. Både hvad angår begrebsafklaringen og de kvantitative undersøgelser, begrænser vi os til danske undersøgelser. Det sker, dels fordi der mangler viden på dette område i Danmark, dels fordi inddragelsen af internationale undersøgelser ville fordre en grundig redegørelse for de forskellige kulturelle kontekster. Blandt andet Sigmund Ongstad fremhæver, at det er vanskeligt at oversætte didaktiske fænomener på tværs af forskellige kulturelle kontekster (Ongstad, 2012, s. 21). Den didaktiske tradition, som vi skriver os ind i, er et kontinentalt fænomen. At redegøre for betydningen af forskellige kulturelle kontekster for forståelsen af undervisningsdifferentiering som begreb, ville være en opgave i sig selv.

Metodisk griber vi undersøgelsen an som dokumentstudier (Lynggaard, 2010). Det betyder, at vi i undersøgelsen betragter de udviklede surveys som dokumenter, dvs. skrevne tekster, der er "sprog, der er fikseret i tekst og tid" (Lynggaard, 2010, s. 138). I analysen fokuseres ikke på tidsdimensionen - men det ligger som en uudtalt forforståelse eller antagelse i analysen og tolkningen, at forskellige operationaliseringer og dermed forskellige forståelser af fænomenet undervisningsdifferentiering også hænger sammen med aktuelle skole- og uddannelsespolitiske diskurser. Surveys som data (og ikke som undersøgelsesmetode) er karakteriseret ved, at de som dokumenter er 
udarbejdet uafhængigt af dokumentanalytikeren. De kan karakteriseres som sekundære dokumenter (Lynggaard, 2010, s. 139). Dokumenterne er udvalgt ud fra dels et relevanskriterium og dels et autoritetskriterium, dvs. at dokumentet er valgt, fordi afsenderen tillægges en særlig central betydning i feltet (Lynggaard, 2010, s. 142), hvilket gælder Danmarks Evalueringsinstitut. Analyserne gennemføres som tekstlæsninger "på tekstens præmisser". Dvs. at vi forsøger at opnå indsigt i den forståelse af undervisningsdifferentiering, som det enkelte dokument er udtryk for. Afslutningsvis opstilles et "display" (Dahler-Larsen, 2008a), som viser en komparativ sammenstilling af tre operationaliseringer (Forster, 2005; Dahler-Larsen, 2008a) med henblik på at diskutere ligheder og forskelle mellem de behandlede operationaliseringer. Vores afslutning indeholder centrale metodiske konklusioner for fremtidige kvantitative undersøgelser af undervisningsdifferentiering og en perspektivering til det grundlæggende spørgsmål om undervisningskvalitet.

\section{Begrebslig klarhed}

Der er utallige udviklingsarbejder og publikationer, der har forsøgt at definere undervisningsdifferentiering (fx Andersen et al., 1992; Christensen \& Rasmussen, 1993; Gabrielsen et al., 1995; Harrit et al., 1993; Krogh-Jespersen \& Striib, 1993; Skibsted et al., 2015). Disse publikationer bygger især på etnografisk inspirerede casestudier, som udpeger konkrete bud på differentiering i bestemte kontekster. Vi dykker ikke konkret ned i de mange forskellige definitioner, men fremhæver en række ejendommelige spændingsfelter. På den ene side bliver begrebet anvendt med en sådan naturlighed og selvfølgelighed, at man forledes til at tro, at der findes en konsensus om det, dvs. én fælles forståelse af dette undervisningsprincip. På den anden side hævdes det for lærernes vedkommende, at der herskede og fortsat hersker en udbredt usikkerhed om, hvordan begrebet skal forstås og tolkes (Danmarks Evalueringsinstitut, 2011b, s. 7). Ser man imidlertid på lærernes svar på Evalueringsinstituttets egne spørgeskemaundersøgelser, tegner der sig et andet billede. I undersøgelsen fra 2004 svarede $99 \%$ ( $n=537)$ af dansklærerne, at de har en klar forståelse af begrebet, og kun $14 \%(n=536)$ angiver, at de har et behov for en nærmere konkretisering heraf (Danmarks Evalueringsinstitut, 2004, s. 5.). I 2011-undersøgelsen svarer $99 \%(n=586)$ af lærerne, at de i nogen eller høj grad har en klar forståelse af, hvad princippet betyder, og 90 \% har en klar forståelse af, hvordan man differentierer undervisning. Samtidig er der kun $4 \%(\mathrm{n}=683)$, der angiver et behov for teoretisk afklaring 
af begrebet. Med andre ord findes den påståede usikkerhed ikke i lærernes selvvurderinger. Alligevel er der noget, der tyder på, at lærernes forståelse af dette undervisningsprincip bør udfordres. Dels konkluderer Evalueringsinstituttets 2011-rapport, at "lærere og lederes forståelse af begrebet er relativt smal" (Danmarks Evalueringsinstitut, 2011b, s. 8). Dels rapporteres det fra udviklingsprojekter, at lærernes beskrivelser og forklaringer af princippet har mange løse ender (Langager, 2015, s. 190). Det er ikke sikkert, at praktikernes forståelse af differentiering er ens. Det er snarere omvendt, således at der formodentligt findes mange forskellige forståelser og praksisser.

Et lignende spændingsfelt findes på det teoretiske niveau. Selvom der findes historiske og analytiske afgrænsninger mod andre forståelser, giver publikationer om undervisningsdifferentiering det indtryk, at der kun findes én gældende forståelse af princippet. Historisk begrundede begrebsdifferentieringer afgrænser undervisningsdifferentiering for eksempel fra elevdifferentiering, som deklareres som et overstået kapitel (Egelund, 2010), afgrænser differentiering fra individualisering af undervisningen (Tetler, 2015) eller fra den forhenværende lighedsfremmende skole, hvor der kun var fokus på ekstra og kompenserende støtte til de lavt præsterende elever (Langager, 2015, s. 192). Modsat de historiske skel mellem før og nu findes der i litteraturen analytiske greb, hvor man skelner mellem to forskellige, men samtidige differentieringsforståelser. Hertil kan man regne Klafkis skelnen mellem indre og ydre differentiering som to sameksisterende praksisser (Klafki, 2001), proaktiv og reaktiv differentiering eller en opdeling i en vertikal, horisontal og samarbejdsdimension (Skibsted, 2015). Bortset fra den sidstnævnte distinktion synes disse greb at favorisere en bestemt forståelse af differentiering, som tilmed er den mest krævende. Man kan ikke kun differentiere i forhold til indhold, metoder, materialer, opgaver, tid, omfang, grupper osv., men i forhold til ethvert didaktisk spørgsmål.

Som en tredje tilgang ved siden af de historiske og analytiske skel findes der det, vi kalder for den loveksegetiske fremgangsmåde. Dette ses i Evalueringsinstituttets 2011-rapport, hvor man søger at identificere en definition ud fra lovmæssige rammesætninger af princippet. Eftersom termen ikke forekommer i lovteksten og eksplicit kun nævnes én gang i bemærkningerne til $\S 18$ stk. 1, konstateres i rapporten næsten beklagende, at loven "ikke direkte [angiver] hvordan lærerne skal opfylde deres forpligtelse", ikke heller "opstiller [...] kriterier for hvornår undervisningen er tilstrækkeligt differentieret" og gennem de sparsomme og metaforiske bestemmelser ikke tilvejebringer et klart grundlag (Danmarks Evalueringsinstitut, 2011b, s. 20.). For alligevel 
at komme frem til en definition af undervisningsdifferentiering griber evalueringsrapporten til både uddannelsespolitiske intentioner som fx en ny evalueringskultur og andre relaterede lovmæssige bestemmelser som fx Klare Mål. Bag en loveksegetisk fremgangsmåde ligger der ikke kun en forventning om lovens klarhed og entydighed, men også en forventning om, at loven omsættes med den højeste grad af opfyldelse. Betragter man folkeskolens lovgivning ud fra ét gældende begreb om differentiering og den højeste grad af fidelitet ved udførelsen, reduceres læreren til en implementeringsagent. Med andre ord fratager man de professionelle pædagogisk ansvar og egen dømmekraft såvel som pædagogisk teori og forskningsselvstændighed som disciplin. I det lys hilser vi det velkomment, at loven er fortolkningsåben.

\section{Fire teoretiske grundpositioner}

Når der bagved såvel historiske, analytiske og loveksegetiske bestemmelser ligger en indforstået antagelse om ét gældende og typisk omfattende begreb for undervisningsdifferentiering, kan det nemt skygge for, at der både i teori og praksis findes forskellige samtidige fortolkninger af dette didaktiske princip. Det er i dette lys, at vi tidligere har gennemført en pragmatisk begrebsanalyse af undervisningsdifferentiering i forbindelse med et kvalitativt eksplorativt litteraturstudie af relevante publikationer tilbage til 1990 (Graf \& Carlsen, 2018, s. 36). I denne analyse identificerede vi fire teoretiske grundpositioner, som adskiller sig ved at have forskellige syn på skolen, undervisning og barnet og ved at have forskellige pædagogiske løsningsforslag. Vi taler om (1) en psykologisk udviklingsorienteret, (2) en didaktisk dannelsesorienteret, (3) en sociologisk læringsudbytteorienteret og (4) en eklektisk funktionalistisk position (Graf \& Carlsen, 2018, s. 37).

Den psykologisk udviklingsorienterede position foreslår pædagogisk differentiering på baggrund af analyser og diagnoser af barnets forudsætninger og potentialer med henblik på det enkelte barns vækst og (identitets)udvikling. Denne hovedsageligt Vygotsky-inspirerede position argumenterer for det størst mulige hensyn til det enkelte barn, hvor fællesskabet udgør det nødvendige stillads. Repræsentanter for denne position findes fra Danmarks Pædagogiske Institut, som foruden Jesper Florander tæller Michael Wahl Andersen, Vagn Rabøl Hansen, Mogens Jansen, Jytte Lau, Inge Horn, Ole Robenhagen og Poul Skov. Varianter af denne position findes for eksempel i differentieret læseundervisning og i Howard Gardners teori om de mange intelligenser. 
Den didaktisk dannelsesorienterede position, som vi har forsøgt at videreudvikle, anskuer differentieringsopgaven i lyset af skolens almendannende opgave. Det vil sige en didaktik for alle med henblik på alsidig interesseudvikling og fokus på det intergenerationelle og kulturbærende indhold. Det heterogene fællesskab er således både forudsætning og mål for den pædagogiske proces hen mod den størst mulige grad af selv- og medbestemmelse i et demokratisk samfund. De didaktiske greb er at reflektere over basale og udvidede indholdsniveauer, opgavetyper, grader af fordybelse og anvendelse ud fra differentiering på baggrund af mængde, kompleksitet, tid/gentagelse, selvstændighed og samarbejde. For denne position har især Klafki-receptionen haft betydning i Danmark.

Den sociologisk læringsudbytteorienterede position, ${ }^{1}$ som især Jens Rasmussen repræsenterer i denne undersøgelse, plæderer for såkaldt intelligent undervisningsdifferentiering. Med afsæt i diagnostiske metoder skal undervisningsdifferentiering bidrage til at maksimere elevernes højst mulige målbare læringsudbytte, samtidig med at betydningen af elevernes socio-økonomiske baggrund mindskes. Eleverne skal blive så dygtige, som de kan. Positionen forstår 'fællesskab' ud fra en systemteoretisk inspireret optik. Når psykiske systemer kommunikerer i rammen af et socialt system, forstås den anden hovedsageligt som en velkommen, men instrumentel forstyrrelse af den enkeltes psykiske system med henblik på maksimal læring.

Den sidste position kalder vi eklektisk funktionalistisk. Der er ikke tale om en position i samme forstand som de tre ovenstående, men snarere en samlebetegnelse for vores tolkning af den omfattende rådgivningslitteratur, som præsenterer mange praksisanvisende regler, fif, tjeklister og redskaber. Disse udgivelser bærer præg af, at de ikke abonnerer på én rammesættende teori, men at de uformidlet og eklektisk trækker på flere og ind imellem teoretisk modstridende ansatser. Vi har kaldt denne brugsorienterede litteratur funktionalistisk, fordi det bagvedliggende rationale er, patchworkagtigt, at præsentere alt, hvad der virker i praksis (Graf \& Carlsen, 2018, s. 37-46).

Vi er af den opfattelse, at det er problematisk direkte at aflede en pædagogik eller didaktik, med andre ord pædagogiske eller didaktiske handlinger, ud fra psykologiske, sociologiske eller andre teorier. Vi mener derfor,

Man kan diskutere om det er velvalgt at kalde denne position for "sociologisk", ligesom Luhmanns systemteori ikke ydes retfærdighed i beskrivelsen. Beskrivelserne beror her udelukkende på den Luhmann-reception, der gøres af Jens Rasmussen i beskrivelsen af såkaldt intelligent undervisningsdifferentiering. Retrospektivt havde det måske været mere adækvat at tale om for eksempel en nytteposition. 
at den dannelsesteoretiske position har den fordel, at der er tale om en almendidaktisk teori på et pædagogisk grundlag. Det betyder, at den dannelsesteoretiske position ser differentieringsopgaven først og fremmest på baggrund af skolens dannelsesopgave, dvs. skolens formål. Med den tilgang forsøgte vi i demonstrationsskoleforsøget Inklusion og differentiering i digitale læringsmiljøer (2013-2015) at videreudvikle den dannelsesteoretiske position under inddragelse af relevante forhold fra den psykologiske og den sociologiske position (se Graf \& Carlsen, 2018, s. 48).

For at nærme os en begrebslig klarhed har vi identificeret tre spændingsfelter og afgrænset undervisningsdifferentiering fra elevdifferentiering og individualiseret differentiering. De fire identificerede differentieringsforståelser peger på mere grundlæggende forskellige differentieringstilgange. $\mathrm{Vi}$ vender nu blikket mod empiriske undersøgelsers operationalisering af lærernes forståelser af og praksis med princippet.

\section{Undervisningsdifferentiering i 2004-rapporten}

De to nævnte kvantitative evalueringsrapporter af undervisningsdifferentiering indeholder mange interessante iagttagelser. For eksempel falder lærernes vurdering tilsyneladende af, i hvilken grad de differentierer deres undervisning, fra 2004 til 2011 fra hhv. $94 \%$ til $89 \%$ (i høj og nogen grad) (Danmarks Evalueringsinstitut, 2004, s. 30; 2011a, s. 26). Og lærernes syn på, om differentiering mest hjælper de fagligt stærke elever og mellemgruppen, falder fra hhv. $95 \%$ og $97 \%$ til $93 \%$ og $92 \%$, mens det stiger fra $88 \%$ til $90 \%$ i forhold til de fagligt svage elever (Danmarks Evalueringsinstitut, 2004, s. 7; 2011a, s. 27.). I det følgende koncentrerer vores interesse sig dog om lærernes forståelse og praktisering af princippet.

Rapporten Undervisningsdifferentiering i folkeskolen (Danmarks Evalueringsinstitut, 2004) undersøger 541 dansklæreres forståelse og vurdering af princippet i praksis og dets rammebetingelser på 285 skoler. Via et spørgeskema undersøges, om lærerne ved, hvad princippet går ud på, om de differentierer deres undervisning, om de er kompetente til at differentiere, om hvilke rammer der fremmer eller hæmmer differentiering, om deres samarbejde om princippet med kolleger og andre, om de opstiller læringsmål, og om de evaluerer og bruger deres evaluering til noget. Sidst, men ikke mindst bliver der spurgt til lærernes praksis med princippet ud fra forskellige undervisningsmetodiske grundformer. Rapporten er således udtryk for en omfattende kortlægning af mange forskellige aspekter af undervisnings- 
differentiering. Til gengæld synes en række spørgsmål at være stillet alt for direkte, dvs. hvor det typiske lærersvar synes at være givet på forhånd - og svarene herpå tillader derfor ikke de store konklusioner. For eksempel vil en lærer næppe angive, at hun ikke forstår eller ikke praktiserer undervisningsdifferentiering, uden samtidigt at skulle diskvalificere sig selv (Danmarks Evalueringsinstitut, 2004, s. 5). Et andet problem er, at den brugte fire-trins Likert-skala ikke tillader nuancerede svar og således kommer til at påvirke svarmulighederne. For eksempel giver det ikke mening at spørge, om en lærer "altid" anvender en bestemt undervisningsform (Danmarks Evalueringsinstitut, 2004, s. 28). Et sådant svar ville udelukke alle andre undervisningsmetoder, og tilslutning til en enkel undervisningsform ville igen stride imod en lærers metodeprofessionalitet.

På trods af sådanne metodiske problemstillinger indeholder undersøgelsen en for os metodisk og indholdsmæssig interessant analyse. I rapporten operationaliseres lærernes differentieringspraksis ud fra seks items om undervisningsformer og en vurdering af disses mulighed for at differentiere: tavleundervisning med spørgsmål til eleverne, eleverne arbejder individuelt $i$ samlet klasse, eleverne arbejder i grupper $i$ temapræget undervisning, elevere arbejder $i$ grupper eller på tværs af fag $i$ tværfaglig undervisning, specialundervisning $i$ rammen af klassen, værkstedsundervisning og undervisning på tværs af klasser (Danmarks Evalueringsinstitut, 2004, s. 28). Disse undervisningsmetodiske former bliver endvidere kombineret med spørgsmålet om graden af differentieringspraksis med henblik på at operationalisere "et tilnærmet mål for lærernes praksis" med undervisningsdifferentiering (se Danmarks Evalueringsinstitut, 2004, s. 31 og 39).

Gennem en såkaldt eksplorativ faktoranalyse af disse items viser sig to bagvedliggende faktorer for differentieringspraksis. En faktoranalyse baserer sig på en statistisk metode, hvor man gennem rotation af variablerne kan identificere, hvilke svar der udvikler sig i (lineær) sammenhæng og på den måde kan tages som udtryk for én bagvedliggende tendens (faktor). På den måde kan flere svar 'reduceres' til en stærkere indikator for noget bagvedliggende. Faktor 1 består af: Lærere, som i højere grad differentierer, anvender værkstedsundervisning, tværfaglige undervisning, undervisning på tværs af klasser, temapræget undervisning og i mindre grad specialundervisning. Faktor 2 viser, at klasseundervisning og tavleundervisning følges ad (Danmarks Evalueringsinstitut, 2004, s. 40). Ved hjælp af faktor 1 dannes der et såkaldt acceptabelt indeks for differentieringspraksis (ny afhængig variabele), som er udgangspunkt for en multivariant regressionsanalyse med de andre signifikante 
svar fra spørgeskemaet (uafhængig variable), som omhandler betingelser for differentieringspraksis. Denne analyse viser, at fleksibilitet $i$ skemaet, kendskab til den enkelte elevs syn på, hvad gør danskfaget spændende, kendskab til den enkelte elevs sociale forhold, ressourcer til og tilgængelighed af undervisningsmaterialer har positiv betydning for differentieringspraksis. Omvendt, men ganske svagt og næsten ikke nævneværdigt, har antal af elever $i$ klassen og uro $i$ klassen en negativ betydning (Danmarks Evalueringsinstitut, 2004, s. 34).

Disse analyser er interessante og giver et bud på en operationalisering af differentieringspraksis og især signifikante relevante rammebetingelser, som vil kunne fremme eller hæmme den. Selvom det undervisningsmetodiske naturligvis indgår som et aspekt $\mathrm{i}$ undervisningsdifferentiering, er der en begrænsning $i$ at definere differentieringspraksis ud fra undervisningsmetodiske storformer. Denne indsigt går helt tilbage til indførelsen af undervisningsdifferentiering i 1993, hvor man netop afgrænsede sig fra at forstå princippet som bestemte undervisningsmetoder (Danmarks Evalueringsinstitut, 2011b, s. 24; Egelund, 2010, s. 14; Hansen et al., 1992). En overvurdering af det metodiske kan nemt føre til en instrumentel og derfor smal forståelse af undervisningsdifferentiering, som paradoksalt nok især knytter sig til subformer for den psykologiske position (Carlsen \& Graf, 2018, s. 40). Men der er også et empirisk og vigtigere argument for at være forsigtig med at operationalisere differentiering gennem undervisningsmetoder. Faktor 2 (klasse- og tavleundervisning) giver det indtryk, at den - modsat faktor 1 - ikke udtrykker differentieringspraksis, selvom $96 \%$ af dansklærerne angiver, at klasseundervisning i nogen og høj grad giver mulighed for differentiering, samtidig med at $89 \%$ af lærerne anvender denne metode ofte. At udelukke klasseundervisning fra en operationalisering af differentieringspraksis giver således ikke mening.

\section{Undervisningsdifferentiering i 2011-rapporten}

I rapporten fra 2011 gøres der meget ud af at definere begrebet undervisningsdifferentiering og koble princippet til det uddannelsespolitiske fokus på evalueringsfaglighed, gennem hvilken man ønsker at styrke lærernes differentieringspraksis. Ved siden af den kvalitative undersøgelse (casestudier på tre skoler) gennemførtes en spørgeskemaundersøgelse med 586 folkeskolelærere på tværs af linjefagsuddannelse med henblik på at kortlægge forhold for og omkring undervisningsdifferentiering. Der spørges til lærernes forståelse og opfattelse af vigtigheden af princippet, til deres arbejde 


\begin{tabular}{|c|c|c|c|}
\hline Undervisningsdifferentiering handler om: & $\begin{array}{l}\text { I høj } \\
\text { grad }\end{array}$ & $\begin{array}{r}\text { I nogen } \\
\text { grad }\end{array}$ & Samlet \\
\hline Lærerens kendskab til egnede metoder & 70,9 & 25,0 & 95,9 \\
\hline Åbne opgaver med forskellige niveauer & 52,6 & 36,6 & 89,2 \\
\hline Læreren sætter mål og evaluerer udbytte & 52,3 & 37,9 & 90,2 \\
\hline Samme emne, forskellige problemstillinger og materialer & 52,1 & 40,5 & 92,6 \\
\hline Læreren viser forskellige forventninger & 45,5 & 33,7 & 79,2 \\
\hline Læreren giver nogle elever mere støtte & 44,8 & 45,5 & 90,3 \\
\hline Læreren imødekommer elevernes læringsstil & 38,8 & 48,5 & $\overline{87,3}$ \\
\hline Elever inddrages i mål og evaluering & 38,1 & 45,5 & 83,6 \\
\hline Læreren tilpasser undervisningen, om målene er nået & 34,4 & 47,0 & 81,4 \\
\hline Læreren tilrettelægger forløb for grupper & 28,9 & 56,1 & $\overline{75,0}$ \\
\hline Læreren inddeler hold med forskellige forudsætninger & 27,0 & 51,8 & 78,8 \\
\hline Forskellige opgaver inden for samme tid & 25,5 & 52,5 & $\overline{78,0}$ \\
\hline Elevers mulighed for at vælge mellem opgaver & 25,1 & 48,9 & 74,0 \\
\hline Læreren sammensætter svage og stærke elever & 22,6 & 55,2 & $\overline{78,8}$ \\
\hline Forskellig tid til samme opgave & 21,5 & 44,8 & 66,3 \\
\hline Læreren tilrettelægger individuelle forløb & 13,5 & 34,2 & 47,7 \\
\hline
\end{tabular}

Tabel 1. Rangordnet overblik over items for differentieringspraksis i EVA's 2011-rapport

med læringsmål og evaluering, planlægning og samarbejde om princippet, lærernes vurdering af egen differentieringspraksis og de dertil oplevede vanskeligheder, lærernes kompetencer og behov for kompetenceudvikling, samt hvordan ledelsen støtter op om at udvikle differentiering på skolerne (Danmarks Evalueringsinstitut, 2011b). Vi interesserer os igen for, hvordan differentieringsforståelser og -praksis er operationaliseret i den kvantitative undersøgelse. Til dette formål har vi samlet alle udsagn, der drejer sig om, hvad undervisningsdifferentiering handler om for lærerne, og derefter rangordnet udsagnene ${ }^{2}$ efter højeste procentsats ud fra svarkategorien $i$ høj grad (tabel 1).

Det er interessant, at differentiering i høj grad handler om metoder, niveauer $i$ opgaver, evaluere læringsmål, forskellige problemstillinger og materialer, have forskellige præstationsforventninger og give udvalgte elever støtte. Omvendt

2 Vi har udeladt udsagn, hvor lærersvar er indlysende ( $\mathrm{fx}$ om læreren bør udfordre eleverne optimalt), samt spørgsmål vedrørende forhold, som læreren ikke har indflydelse på (fx om eleverne er bevidste om deres forudsætninger). 
handler undervisningsdifferentiering mindre om individuelle forløb, differentieret tid, bevidst heterogene grupper, elevernes valgmuligheder, forskellige opgaver inden for samme tid, mere homogene hold med forskellige forudsætninger og forløb for grupper. Sat på spidsen synes lærerne, at differentiering i høj grad handler om metoder og i mindste grad om individuelle forløb. Faren for individualisering af undervisningen, som somme tider bliver fremhævet, synes ikke at være lærernes selvopfattelse, men snarere omvendt: Frem for individuelle forløb skal undervisningsdifferentiering realiseres gennem almene undervisningsmetodiske greb i den fælles undervisning. Dette stemmer som svag tendens også overens med undersøgelsens eneste spørgsmål til lærernes praksis, hvor 93\% svarer, at de i nogen og høj grad differentierer gennem undervisningsformer. Men omvendt må man konstatere, at når $89 \%$ samtidigt differentierer gennem materialer og undervisningsmidler og 77\% gennem indhold, så er forskellene ikke store. En opgørelse af differentieringspraksis på denne måde synes generelt ikke at tillade de store konklusioner. Hvad skal vi bruge det til, at der er lidt forskel mellem differentiering gennem metoder, materiale eller indhold? Desuden er kategorierne ikke skarp adskilte. Når man differentierer gennem materialer, differentierer man vel også samtidig gennem indhold.

Ligesom med 2004-rapporten skal man også for 2011-rapporten kritisk undersøge designet af spørgeskemaet. Modsat 2004-rapporten, hvor man mere direkte spørger til lærernes praksis og opstiller et tilnærmet indeks for denne, stiller 2011-rapporten som sagt kun ét spørgsmål til differentieringspraksis. At spørge til praksis i spørgeskemaer er ikke nemt. For det første skal man forlade sig på respondenternes selvvurdering, hvor det naturlige positive selvbillede af ens professionelle praksis vil skinne igennem. For det andet er praksis kompleks og kontekstafhængig. Når man har differentieret $\mathrm{i}$ den ene klasse, men ikke i den anden, når man har differentieret med opgaver i matematik, men gennem selvstændighed i billedkunst, eller når man i sidste uge har indholdsdifferentieret, men i denne uge materialedifferentieret, hvordan skal man så svare på generelle spørgsmål om grader af differentieringspraksis?

For det tredje er den anvendte fire-trins Likert-skala problematisk. Når der i forhold til pædagogisk praksis spørges til "altid", "aldrig" eller "slet ikke" som skalaens yderpunkter, bliver der kun få svarmuligheder tilbage. Både 2004- og 2011-rapporten indeholder svar, som har en meget ens fordeling, hvor mange af yderpunkterne er tæt på nul. Hvilken lærer ønsker for eksempel ikke at udfordre alle elever optimalt, eller hvilken lærer ønsker sig 
ikke mere tid til forberedelse eller bedre ressourcer (Danmarks Evalueringsinstitut, 2011a, s. 17 og 28)?

Der er behov for at udvikle bedre spørgsmålsdesigns, som kan indfange den pædagogisk relevante variation, tage højde for idealiserende svar og bedre identificere den selvrapporterede praksis. Vi har selv forsøgt at dokumentere differentieringspraksis gennem spørgeskemaundersøgelser. Det ser vi på i de næste afsnit.

\section{Undervisningsdifferentiering i demoskoleforsøgene og i Esbjerg kommune}

I forbindelse med AUUC-konsortiets tre demonstrationsskoleforsøg blev gennemført en base- og endline-undersøgelse indeholdende et spørgsmålsbatteri om differentieringspraksis. Selve virkningsevalueringen kunne dokumentere en række interessante resultater. For eksempel oplever lærerne efter projektet Inklusion og differentiering $i$ digitale læringsmiljøer i højere grad, at it kan bruges til undervisningsdifferentiering (Hansen \& Bundsgaard, 2016, s. 32). Samtidig viser en kvantitativ analyse af elevprodukter i fagene dansk, matematik og naturfag på tværs af tre demonstrationsskoleforsøg, at "[l]ærernes opgavestillinger er kendetegnet ved dels at instruere i reproduktion af viden, dels at mangle støtte til undervisningsdifferentiering." (Hansen \& Bundsgaard, 2016, s. 22).

I undersøgelsen, som blev besvaret af 390 lærere fra 15 skoler fordelt over hele Danmark, var der kun plads til et spørgsmålsbatteri med ti items for undervisningsdifferentiering på en seks-trins Likert skala. For at imødegå idealiserende svar valgte man for alle spørgsmål angående lærernes praksis at spørge til lærerens sidste undervisningsforløb. Selvom denne spørgeteknik også kan forvrænge ønsket om et generelt billede af praksis, kan den bruges, når det drejer sig om større datasæt. Den eksplorative faktoranalyse af de ti items for baseline-data identificerer to faktorer, som blev kaldt traditionel (faktor 1) og selvstændig (faktor 2) (se tabel 2). Faktor 1, traditionel differentiering, som indeholder inddele elever i forskellige hold, variere opgavernes sværhedsgrad, anskueliggøre indholdet, give supplerende opgaver, kompensere for faglige mangler, lade eleverne arbejde med forskellige problemstillinger og stotte og strukturere udvalgte elevers arbejdsproces, udviser en god reliabilitet gennem Cronbach Alpha, og faktor 2, selvstændig differentiering, som indeholder items som at give specifik feedback til den enkelte eller mindre grupper, lade eleverne selv 
styre deres arbejdsproces og lade eleverne give hinanden respons eller støtte, har en acceptabel reliabilitet (Pettersson et al., 2015, s. 52).

\section{TABEL 36. FAKTORLOADINGS PÅ BAGGRUND AF EKSPLORATIV FAKTORANALYSE}

\begin{tabular}{l|c|c}
\hline Indikatorer & Faktor1 & Faktor 2 \\
\hline -inddele eleverne i forskellige hold &, 650 &,- 038 \\
\hline -variere opgavernes sværhedsgrad? &, 863 &,- 162 \\
\hline -anskueliggøre indholdet på forskellige måder &, 535 &, 225 \\
\hline -give udvalgte elever supplerende opgaver &, 735 &,- 051 \\
\hline -kompensere for udvalgte elevers faglige mangler &, 807 &,- 006 \\
\hline -lade eleverne arbejde med forskellige problemstillinger &, 709 &, 163 \\
\hline -støtte og strukturere nogle elevers arbejdsproces mere end andres &, 513 &, 408 \\
\hline -give specifik feedback til den enkelte eller mindre grupper &, 421 &, 548 \\
\hline -lade eleverne selv styre deres arbejdsproces &,- 127 &, 833 \\
\hline -få eleverne til at give hinanden respons eller støtte hinanden &, 084 &, 768 \\
\hline
\end{tabular}

Note: Faktoranalysen udtrækker to faktorer. Faktorloadings viser korrelationen for et item og den latente variabel. $\mathrm{N}=390$. Intern reliabilitet for Faktor 1 (Alpha $=0.847$ ). Intern reliabilitet for Faktor 2 (Alpha= 0.701)

Tabel 2. Eksplorativ faktoranalyse for differentieringspraksis ved Demonstrationsskoleforsøg

Traditionel differentiering er klart den stærkeste faktor og forklarer $46 \%$ af variationen (Eigenværdi 4,66), mens faktor 2 blot forklarer $12 \%$ af variationen, og derfor ikke er så stærk. De bivariate analyser mellem indekset og fx køn, klassetrin, anciennitet, fag og fagforståelse viser ikke væsentlige forskelle mellem den traditionelle og selvstændige differentieringsfaktor (Pettersson et al., 2015, s. 53).

Helt præcist de samme spørgsmål til undervisningsdifferentiering blev stilleti en undersøgelse af samtlige læreres praksis med elevfeedbacki Esbjerg kommune i 2015 (Graf \& Carlsen, 2016). I forbindelse med en kommunal udviklingsindsats afprøvede man Elevbaro.dk, et digitalt, kontekstsensitivt redskab til elevfeedback, som vi har udviklet i demonstrationsskoleforsøget Inklusion og differentiering $i$ digitale læringsmiljøer. Mens andre tiltag med at 
styrke evalueringskulturen har fokuseret på lærerens evaluering af læringsmål (jf. Danmarks Evalueringsinstitut, 2011b), har vi ønsket at give eleverne mulighed for dels systematisk at ytre sig om deres læringssituation, dels at aktivere deres egne og fælles metakognitive refleksioner. Vi anser systematisk elevfeedback som en god mulighed for lærere for at udvikle deres differentieringspraksis (Graf \& Carlsen, 2018).

Faktoranalysen af de ti items for undervisningsdifferentiering, med denne gang 428 folkeskolelærere fra 27 skoler i én kommune, bekræfter resultaterne fra Demonstrationsskoleforsøgene. Der dannes præcis de samme to faktorer, dog med lidt mindre forklaringskraft (Eigenværdi faktor 1: 3,05; faktor 2: 1,46) (Graf \& Carlsen, 2016, s. 20).

\section{Undervisningsdifferentiering i Digital projektdidaktik med de frie skoler}

Der er blevet gennemført endnu en måling af læreres differentieringspraksis: nu med otte frie grundskoler i forbindelse med et udviklingsarbejde om Inkluderende digital projektdidaktik $i$ de frie skoler (2016-2018) (www.digitalprojektdidaktik.dk). Interventionen er en videreudvikling af Inklusion og differentiering i digitale læringsmiljøer, men fokuserer på at udvikle undervisningen hen mod projektorienterede forløb med inddragelse af it for både lærere og elever. Den gennemførte base-/endline-måling læner sig op ad virkningsevalueringen fra demonstrationsskoleforsøgene, men søger at videreudvikle målingen af lærernes differentieringspraksis. De to faktorer traditionel og selvstændig differentiering synes ikke at være tilfredsstillende mål i lyset af det teoretiske arbejde, som førte til de fire ovennævnte grundpositioner. Ud over at gennemføre en virkningsevaluering var det et delformål med den ændrede operationalisering af differentieringspraksis at undersøge, om ikke det er muligt at identificere forskellige grundpositioner hos lærerne. Spørgsmålsbatteriet fra demonstrationsskoleforsøgene blev derfor udvidet fra 10 til 12 items og justeret (se tabel 3). I det nye spørgeskema er det igen magtpåliggende, at lærerne ikke svarer ud fra en generel fornemmelse, men helt konkret ud fra det sidst gennemførte forløb i deres hovedfag, med en klasse, de har mange timer med. Spørgsmålenes formulering med "jeg tilrettelagde ..." eller "jeg delte ..." skulle understrege opfordringen til at svare ud fra konkret praksis.

Ser vi på paneldata i tabel 3, dvs. en sammenligning af før og efter for hver enkelt respondent, kan vi konstatere en række ændringer i lærernes 
differentieringspraksis. Ser man på items, som både ved base- og endline ligger over gennemsnitlig fire skalatrin, kan man konstatere, at lærerne har praktiseret elev-elev-støtte, støtte af udvalgte elever og frelles opsamlinger. Disse hovedkarakteristika for lærernes differentieringspraksis har imidlertid ikke ændret sig fra før til efter. Ved endline kommer også forventningstilpasning og feedback til enkelte elever over fire gennemsnitlige skalatrin. Ser vi omvendt på, hvilken praksis der er mindre anvendt (<3), kan man fremhæve følgende items: danne homogene grupper, kompensation for udvalgte elever og varieret tilegnelse, hvoraf de to sidste dog ændrer sig betydeligt fra før til efter.

\begin{tabular}{|c|c|c|c|c|c|c|}
\hline \multirow[b]{2}{*}{ Label } & \multicolumn{2}{|c|}{ Baseline } & \multicolumn{2}{|c|}{ Endline } & \multicolumn{2}{|c|}{ Panel } \\
\hline & Mean & $\begin{array}{c}\text { Std. } \\
\text { Deviation }\end{array}$ & Mean & $\begin{array}{c}\text { Std. } \\
\text { Deviation }\end{array}$ & Udvikling & Chi-Square \\
\hline Danne homogene grupper & 2,16 & 1,56 & 2,14 & 1,43 & $-0,01$ & 845 \\
\hline Elev-elev-st $\varnothing$ tte & 4,21 & 1,54 & 4,14 & 1,50 & $-0,07$ & ,791 \\
\hline Støtte af udvalgte elever & 4,43 & 1,34 & 4,63 & 1,35 & 0,19 &, 540 \\
\hline Kompensation for udvalgte elever & 2,57 & 1,68 & 2,89 & 1,73 & 0,33 & ,731 \\
\hline Opgavetilpasning & 3,59 & 1,49 & 3,87 & 1,47 & 0,28 & 851 \\
\hline Materialetilpasning & 3,55 & 1,71 & 3,60 & 1,77 & 0,05 &, 968 \\
\hline Læremiddeltilpasning & 3,64 & 1,79 & 3,24 & 1,76 & $-0,40$ & ,687 \\
\hline Varieret anskueligg ørelse & 3,63 & 1,70 & 3,95 & 1,58 & 0,32 & ,791 \\
\hline Varieret tilegnelse & 2,88 & 1,57 & 3,34 & 1,48 & 0,46 &, 020 \\
\hline Forventningstilpasning & 3,68 & 1,51 & 4,23 & 1,41 & 0,54 & 098 \\
\hline Feedback til enkelte elever & 3,82 & 1,55 & 4,25 & 1,52 & 0,44 &, 357 \\
\hline Fælles opsamlinger & 4,07 & 1,45 & 4,14 & 1,36 & 0,08 &, 925 \\
\hline
\end{tabular}

Note: Baseline $\mathrm{N}=76$ Endline $\mathrm{N}=83=81,1$ procent

Tabel 3. Måling af differentieringspraksis i Digital projektdidaktik

Eftersom der ikke er anvendt en kontrolgruppe, kan det ikke udelukkes, at de synlige ændringer skyldes andet end projektets intervention. Som signifikanstesten (Chi-Square) angiver, er der derudover betydelige usikkerheder for de fleste ændringer, som kan skyldes mange ting, men i hvert fald hænger sammen med det begrænsede antal respondenter $(n=76, n=83)$. Alligevel kan vi iagttage udviklingstendenser ${ }^{3}$ for opgavetilpasning, varieret anskueliggørelse, kompensation for udvalgte elever, feedback til enkelte elever og varieret tilegnelse (signifikant for $<0,05$ ). For forventningstilpasning kan vi konstatere den mest

3 Eftersom der er brugt en seks-trins Likert-skala, kan man gå ud fra, at en gennemsnitlig ændring på et kvart skalatrin $(0,25)$ er en tendens, mens en ændring på et halvt skalatrin $(0,5)$ er en betydelig udvikling, især når gennemsnittet (mean) ved baseline enten allerede er høj (fx $>4$ ) eller lav ( $f x<2$ ). 
markante ændring (signifikant for $<0,1$ ) ud fra et gennemsnitligt baseline-niveau på 3,68 skalatrin. Der viser sig også en tydelig tilbagegang på 0,4 for læremiddeltilpasning fra et gennemsnitligt niveau på 3,64 ved baseline.

\section{Operationaliseringer i sammenligning}

Afslutningsvis opstiller vi et display, der sammenligner de ovenfor diskuterede operationaliseringer. Eftersom 2004-rapporten operationaliserer differentieringspraksis på en grundlæggende anden måde, nemlig ud fra metodiske storformer, er den udeladt i nedenstående sammenstilling (tabel 4). Vi har taget udgangspunkt i det fælles spørgeskema for Demonstrationsskoleforsøget og Esbjerg-undersøgelsen og knyttet items fra de andre undersøgelser sammen i samme række. Ved en række items er der tæt på identitet, men ved de fleste er der enten nuanceforskel eller betydelige afvigelser. Desuden er der en del items, som ikke har nogen affinitet med tilsvarende items fra de andre undersøgelser. 2011-rapporten (til venstre) indeholder den ovenfor indførte inddeling i meget relevante (lysegrøn), relevante (uden farve) og mindre relevante (mørkegrøn) indikatorer på differentieringspraksis. For midterkolonnens vedkommende angiver den lyserøde farve traditionel og den mørkerøde farve selvstændig differentiering. Vedrørende Digital projektdidaktik er der gennemført eksplorative faktoranalyse af de 12 items for både base- og endline, som vi repræsenterer kombineret. Ved baseline-målingen viser der sig tre faktorer (Agergaard et al., 2017a, s. 27). Ved endline-målingen viser der sig fire faktorer (Agergaard et al., 2017b, s. 27). Lilla viser faktor 1 ved både base- og endline, som især indeholder items, der udtrykker en særlig hensyntagen til udvalgte elever. Blå er faktor 2 ved både base- og endline og vedrører især anskueliggørelse og fokus på forskellige måder at lære på. Lyseblå er faktor 3 for både base- og endline og indeholder differentiering i forhold til materialer og læremidler. Lyserødt er faktor 4 ved endline og kredser om tilpassede opgaver til mere homogene hold. Hvid er et item, som skifter fra base- til endline.

Det er tydeligt, at de synoptisk opstillede operationaliseringer af differentiering både viser ligheder og forskelle. En tværgående problemstilling ved flere items er, at de i grunden indeholder flere elementer. For eksempel "Opstille forskellige læringsmål og variere opgavers sværhedsgrad" er i grunden to forskellige indikatorer. Den slags metodiske problemstillinger, hvor items er vanskelige at skelne fra hinanden, begrænser nuancerede målinger og tydelige faktordannelser. En anden metodisk problemstilling 


\begin{tabular}{|c|c|c|}
\hline 2011-rapport & $\begin{array}{l}\text { Demonstrationsskole + } \\
\text { Esbjerg }\end{array}$ & Digital projektdidaktik \\
\hline $\begin{array}{l}\text { Læreren inddeler hold med } \\
\text { forskellige forudsætninger }\end{array}$ & $\begin{array}{l}\text { Inddele eleverne i forskellige } \\
\text { hold }\end{array}$ & $\begin{array}{l}\text { Jeg delte eleverne ind i hold } \\
\text { med samme forudsætninger } \\
\text { (homogene grupper) }\end{array}$ \\
\hline \multirow[t]{2}{*}{$\begin{array}{l}\text { Samme emne, forskellige } \\
\text { problemstillinger og mate- } \\
\text { rialer }\end{array}$} & $\begin{array}{l}\text { Lade eleverne arbejde med } \\
\text { forskellige problemstillinger } \\
\text { og aktiviteter inden for det } \\
\text { samme forløb }\end{array}$ & $\begin{array}{l}\text { Jeg tilrettelagde forskellige } \\
\text { måder at lære på til de fælles } \\
\text { aktiviteter (varieret tileg- } \\
\text { nelse) }\end{array}$ \\
\hline & $\begin{array}{l}\text { Anskueliggøre indholdet på } \\
\text { forskellige måder }\end{array}$ & $\begin{array}{l}\text { Jeg anskueliggjorde det } \\
\text { faglige på forskellige måder } \\
\text { (varieret anskueliggørelse) }\end{array}$ \\
\hline $\begin{array}{l}\text { (Elevers mulighed for at } \\
\text { vælge mellem opgaver) }\end{array}$ & $\begin{array}{l}\text { Lade eleverne selv styre } \\
\text { deres arbejdsproces }\end{array}$ & $\begin{array}{l}\text { Jeg brugte digitale læremid- } \\
\text { ler, som giver eleverne mulig- } \\
\text { hed for at vælge forskellige } \\
\text { sværhedsgrader (læremid- } \\
\text { deltilpasning) }\end{array}$ \\
\hline \multirow[t]{2}{*}{$\begin{array}{l}\text { (Læreren tilrettelægger } \\
\text { forløb for grupper) }\end{array}$} & $\begin{array}{l}\text { Give udvalgte elever supple- } \\
\text { rende opgaver }\end{array}$ & \multirow{2}{*}{$\begin{array}{l}\text { Jeg gav supplerende eller } \\
\text { kompenserende opgaver til } \\
\text { udvalgte elever for at træne } \\
\text { specifikke færdigheder } \\
\text { (kompensation for udvalgte } \\
\text { elever) }\end{array}$} \\
\hline & $\begin{array}{l}\text { Kompensere for udvalgte } \\
\text { elevers faglige mangler }\end{array}$ & \\
\hline $\begin{array}{l}\text { Læreren sætter mål (og eva- } \\
\text { luerer udbytte) } \\
\text { Læreren viser forskellige } \\
\text { forventninger }\end{array}$ & $\begin{array}{l}\text { Opstille forskellige lærings- } \\
\text { mål og variere opgavernes } \\
\text { sværhedsgrad }\end{array}$ & $\begin{array}{l}\text { Jeg tilpassede mine for- } \\
\text { ventninger og læringsmål } \\
\text { til udvalgte elever (forvent- } \\
\text { ningstilpasning) }\end{array}$ \\
\hline \multirow[t]{3}{*}{$\begin{array}{l}\text { Læreren giver nogle elever } \\
\text { mere støtte }\end{array}$} & $\begin{array}{l}\text { Støtte og strukturere nogle } \\
\text { elevers arbejdsproces mere } \\
\text { end andres }\end{array}$ & $\begin{array}{l}\text { Jeg gav særlig hjælp til } \\
\text { udvalgte elever (støtte af } \\
\text { udvalgte elever) }\end{array}$ \\
\hline & $\begin{array}{l}\text { Give specifik feedback til den } \\
\text { enkelte eller mindre grupper }\end{array}$ & $\begin{array}{l}\text { Jeg gav specifik feedback til } \\
\text { udvalgte elever (feedback til } \\
\text { enkelte elever) }\end{array}$ \\
\hline & $\begin{array}{l}\text { Få eleverne til at give hin- } \\
\text { anden respons og støtte } \\
\text { hinanden }\end{array}$ & $\begin{array}{l}\text { Jeg tilrettelagde undervis- } \\
\text { ningen, således at eleverne } \\
\text { støttede hinanden (Elev-elev- } \\
\text { støtte) }\end{array}$ \\
\hline \multirow[t]{2}{*}{$\begin{array}{l}\text { Åbne opgaver med forskel- } \\
\text { lige niveauer }\end{array}$} & & $\begin{array}{l}\text { Jeg brugte undervisnings- } \\
\text { materiale, som indeholder } \\
\text { opgaver med forskellige } \\
\text { sværhedsgrader (materiale- } \\
\text { tilpasning) }\end{array}$ \\
\hline & & $\begin{array}{l}\text { Jeg gav grupperne opga- } \\
\text { ver, som passede til deres } \\
\text { kunnen (opgavetilpasning) }\end{array}$ \\
\hline
\end{tabular}




\begin{tabular}{|c|c|c|}
\hline 2011-rapport & $\begin{array}{l}\text { Demonstrationsskole + } \\
\text { Esbjerg }\end{array}$ & Digital projektdidaktik \\
\hline & & $\begin{array}{l}\text { Jeg samlede jævnligt op i } \\
\text { klassen, så de enkelte bidrag } \\
\text { kunne blive drøftet og værd- } \\
\text { sat (fælles opsamlinger) }\end{array}$ \\
\hline \multicolumn{3}{|l|}{$\begin{array}{l}\text { Lærerens kendskab til } \\
\text { egnede metoder }\end{array}$} \\
\hline \multicolumn{3}{|l|}{$\begin{array}{l}\text { Læreren imødekommer ele- } \\
\text { vernes læringsstil }\end{array}$} \\
\hline \multicolumn{3}{|l|}{$\begin{array}{l}\text { Eleverne inddrages i mål og } \\
\text { evaluering }\end{array}$} \\
\hline \multicolumn{3}{|l|}{$\begin{array}{l}\text { Læreren tilpasser undervis- } \\
\text { ningen, om målene er nået }\end{array}$} \\
\hline \multicolumn{3}{|l|}{$\begin{array}{l}\text { Forskellige opgaver inden for } \\
\text { samme tid }\end{array}$} \\
\hline \multicolumn{3}{|l|}{$\begin{array}{l}\text { Læreren sammensætter fag- } \\
\text { ligt svage og stærke elever }\end{array}$} \\
\hline \multicolumn{3}{|l|}{$\begin{array}{l}\text { Forskellig tid til samme } \\
\text { opgave }\end{array}$} \\
\hline $\begin{array}{l}\text { Læreren tilrettelægger indivi- } \\
\text { duelle forløb }\end{array}$ & & \\
\hline
\end{tabular}

Tabel 4. Komparativ opstilling af tre former for operationalisering af differentieringspraksis

er, hvordan man reelt identificerer praksis. Ud over de allerede diskuterede problemstillinger, spørgsmålenes klarhed og konkrethed og skalaens omfang indeholder de anvendte spørgsmålsbatterier ikke nogen modstand, som gør, at respondenterne faktisk skal bruge deres professionelle dømmekraft for at vælge mellem flere muligheder i en given pædagogisk situation. Valget mellem for eksempel indholds-, materiale- eller metodedifferentiering kan ikke besvares $i$ et uendelighedsperspektiv, men må afhænge af konkrete forhold, som enten afgør det ene eller det andet, eller en kombination. En mulighed for at videreudvikle spørgeskemaer, som tager højde for professionelle valg, udgør undersøgelser, som bygger på dilemmaer, som vi kender dem fra studier af moralsk dømmekraft. Et tiltag i denne retning er den såkaldte vignetmetode, som Morten Ejrnæs har videreudviklet i forbindelse med undersøgelser af pædagogers praksis (Ejrnæs \& Monrad, 2012).

Ser man indholdsmæssigt på spørgsmålene, er der en del overlap på tværs af de tre undersøgelser, som kunne være et godt udgangspunkt for nye målinger. Det gælder fx inddeling i hold, lade elever arbejde med forskellige pro- 
blemstillinger, samarbejde om læringsmål, støtte udvalgte elever m.m. Men disse items er usystematisk kombineret i forhold til en realistisk pædagogisk valgsituation. Mens 'inddeling i hold' er et proaktivt planlægningsvalg, er 'støtte af udvalgte elever' typisk en stilladsering i undervisningsprocessen. Mens 'opstille læringsmål sammen med elever' foregår i samtaler med dem, er det noget andet 'at give supplerende opgaver', når de hurtigste elever er færdige. De anvendte spørgsmålsbatterier indeholder ikke en operationalisering, som systematisk bygger på didaktisk teori eller pædagogisk funderet professionsteori. Når det viser sig, at x \% af lærerne indholdsdifferentierer, ved man ikke, hvad det skal ses i forhold til, eller om det har været et adækvat valg. Selvom mange af de anvendte items er brugbare, så er det ikke sikkert, at de identificerer didaktisk væsentlige forskelle mellem forskellige differentieringspraksisser. Didaktisk teori skal tilvejebringe en systematik over differentieringsmuligheder. Her har vi foreslået en didaktisk strukturmodel, hvor de enkelte kategorier er bragt $\mathrm{i}$ en begrundet sammenhæng med henblik på elevernes tilegnelse (Carlsen \& Graf, 2018; Graf, 2012).

En anden problemstilling er, hvilket professionsteoretisk fundament for differentieringspraksisser man kunne anvende. Vi har i første omgang koncentreret os om didaktisk differentiering, hvor det drejer sig om planlægning, gennemførelse og evaluering af differentieret undervisning med henblik på elevernes faglige deltagelse og tilegnelse. Ud fra en didaktisk tilgang er det imidlertid fortsat oplagt at skele til den psykologiske positions fokus på elevens trivsel og identitetsdannelse i forbindelse med social læring og til den sociologiske positions ambition om højst mulige og kontekstsensitive forventninger til eleven. Endvidere indeholder en opdateret lærerprofessionalitet i vores forståelse også en moderat tilgang til testning, diagnosticering, evaluering og elevfeedback. For at fremme differentiering er der således i høj graf brug for et dobbeltperspektiv. Man kan ikke nøjes med kun at se på lærerens handlinger, men bør også inddrage elevperspektivet. Hvordan oplever elever balancen mellem udfordring og mestring, og hvordan kommer lærerne i besiddelse af enkelt, systematisk elevfeedback med henblik på adækvate differentieringstiltag, jf. Elevbaro.dk (Graf \& Carlsen, 2018). Udvider man endvidere det psykologiske blik på eleven til et holistisk pædagogisk blik på elevens tilblivelse og dannelse, bliver yderligere kriterier synlige. Hvordan indfanger man $\mathrm{fx}$ differentiering $\mathrm{i}$ forhold til dannelsesmålet selvbestemmelse? Og hvordan får man et blik for eleven i konteksten af skolen, familien og fritid? 


\section{To teser og et perspektiv}

I lyset af denne første komparative og kritiske analyse af udvalgte kvantitative målinger af undervisningsdifferentiering må vi konkludere, at der blandt disse endnu ikke findes en accepteret målemetode af differentieringspraksis. På den baggrund formoder vi, at andre undersøgelser af differentiering igen har andre målemetoder og derfor måler andre forhold. Det gør, at undersøgelsernes resultater ikke er umiddelbart sammenlignelige. Mere alment formuleret kan man sige, at der endnu ikke findes en bredt accepteret og valideret indikator for undervisningsdifferentiering, som ville kunne bidrage til udvikling af både forskningsfeltet og praksisfeltet. I dette konkluderende afsnit opsummerer vi en række centrale hjørnestene for metodisk videreudvikling af målinger af differentieringspraksis. Disse konklusioner formuleres i to centrale teser, som gensidigt betinger hinanden.

- Der er for det første behov for en endnu bedre teoretisk afklaring af et begreb om differentieringspraksis på pædagogisk grundlag, som er operationaliserbart i form af spørgeskemaer og andre målemetoder, og som gør det muligt at identificere de i praksis relevante og betydningsfulde forskelle. Det betyder, at der ikke kun kan indgå items for differentieringspraksis, men også relevante kontekstfaktorer og lærernes didaktiske intentionalitet i det hele taget. En indikator for lærernes differentieringspraksis uden et mål for elevernes optimale udfordring med den, taster i grunden i blinde. Vi ved i grunden ikke, om en differentieringspraksis har den betydning, som den tilskrives. Dette sidste punkt gør målinger af differentiering meget udfordrende og vanskeligt.

- For det andet er der behov for en grundig validering af spørgeskemaer og andre målemetoder, så vi kan være sikre på, at måleinstrumenterne måler det, de foregiver at måle. Det er i hvert fald blevet tydeligt, at spørgeskemaundersøgelser, som alene baserer sig på lærernes selvrapportering, indeholder tentative spørgsmål og er helt kontekstfri, er problematiske. Det betyder, at der ikke kun skal gennemføres pretests, hvor typiske fordelinger, varianser samt respondentanalyser prøves, men at de forskellige items indfanger praksisrelevante forskelle, som med fordel baserer sig på kvalitative studier. En teoribaseret og valideret metodisk tilgang vil så give mulighed for at gå væk fra eksplorative, dvs. svage, faktoranalyser og erstatte dem med konfirmerende faktoranalyser, som tester på forhånd definerede sammenhænge. I det hele taget er der behov for at tænke over det metodiske design for 
fremtidige målinger af differentieringspraksis. Med henblik på mere kontekstsensible målinger, som samtidigt identificerer lærernes professionelle dømmekraft i dilemmafyldte differentieringssituationer, kunne det være interessant at videreudvikle den såkaldte vignetmetode (Ejrnæs \& Monrad, 2012; Graf \& Christensen, 2020). I vignetundersøgelser skal respondenterne svare ud fra små virkelighedsnære fortællinger, som repræsenterer en udfordring i praksis.

Afslutningsvis knyttes an til artiklens introduktion, hvor vi tematiserede spørgsmålet om kvalitet. Hvad er i grunden kvalitet i undervisningsdifferentiering? Igennem artiklen har vi flere gange gjort opmærksom på, at kravet om differentiering er omfattende og ambitiøst. Det er indlysende, at man kan differentiere ud fra hver eneste didaktiske kategori. På den måde afhænger differentieringsbegrebet af den eksplicitte eller implicitte didaktiske teori, dvs. teoriens centrale didaktiske kategorier. Helt overordnet kan man ikke kun differentiere ud fra mål/indhold, undervisningsmetoder (i rum og tid) og medie-(re)præsentation, men også ud fra de mange forskellige typer af elevforudsætninger og undervisningens kontekstfaktorer. Vi hævder, at princippet om undervisningsdifferentiering er grænseløst. Som lærer kan det opleves, som om man aldrig har gjort nok. Når man kan differentiere ud fra alle didaktiske kategorier, og når vi kan parafrasere undervisningsdifferentiering som at give hvert enkelt elev optimale lærings- og deltagelsesbetingelser i klassens arbejdsfællesskab, så er undervisningsdifferentiering i realiteten ikke andet end kvalitet i undervisning. Måske er undervisningsdifferentiering ikke andet end almendidaktik, og differentieringspraksis er ikke andet end god undervisning? Hvis ja, kunne målinger af underdifferentiering med fordel knytte an til indsigter fra forskningen i kvalitet i undervisning.

\section{Referencer}

Agergaard, K., Graf, S.T., Weiglin, R., \& Puck, M.R. (2017a). Inkluderende digital projektdidaktik $i$ de frie skoler - Teknisk rapport fra lærersurvey baseline. Nationalt Videncenter for Frie Skoler.

Agergaard, K., Graf, S.T., Weiglin, R., \& Puck, M.R. (2017b). Inkluderende digital projektdidaktik $i$ de frie skoler - Teknisk rapport fra lærersurvey endline. Nationalt Videncenter for Frie Skoler og Center for Anvendt Skoleforskning.

Agergaard, K., Graf, S.T., Weiglin, R., \& Puck, M.R. (2017c). Inkluderende digital projektdidaktik $i$ de frie skoler - Teknisk rapport fra lærersurvey panel. Nationalt Center for Frie Skoler og Center for Anvendt Skoleforskning.

Andersen, M.W., Jansen, M., \& Lau, J. (1992). Undervisningsdifferentiering 2 - forudsætninger og praksis. Danmarks Pædagogiske Institut. 
Carlsen, D., \& Graf, S.T. (2018). Fire differentieringspositioner og deres didaktiske konsekvenser. I: Bundsgaard, J., Hansen, T.I., Georgsen, M., Graf, S.T., \& Skott, C. K. (red.), Innovativ undervisning med it - Forskning i tre demonstrationsskoleforsøg II (s. 34-60). Århus Universitetsforlag.

Christensen, D., \& Rasmussen, K. (1993). Undervisningsdifferentiering - set gennem praksis. Danmarks Lærerforening.

Dahler-Larsen, P. (2008a). Displaying qualitative data. Syddansk Universitetsforlag.

Dahler-Larsen, P. (2008b). Konsekvenser af indikatorer. KREVI.

Danmarks Evalueringsinstitut (2004). Undervisningsdifferentiering i folkeskolen.

Danmarks Evalueringsinstitut (2011a). Tabelrapport til Undervisningsdifferentiering som bærende pædagogisk princip.

Danmarks Evalueringsinstitut (2011b). Undervisningsdifferentiering som bærende pædagogisk princip : en evaluering af sammenhænge mellem evalueringsfaglighed og differentieret undervisning.

Danmarks Evalueringsinstitut og Undervisningsministeriet (2017). Undervisningsdifferentiering i grundskolen. Vidensnotat.

Egelund, N. (2010). Elevdifferentiering og undervisningsdifferentiering. I: Egelund, N. (red.), Undervisningsdifferentiering: status og fremblik (Vol. 1., s. 9-16). Dafolo.

Ejrnæs, M., \& Monrad, M. (2012). Vignetmetoden : sociologisk metode og redskab til faglig udvikling. Akademisk Forlag.

Forster, A. (2005). A Non-Linear Model of Information Seeking Behaviour. Information Research, 10(2).

Gabrielsen, G., Hach, C., Nipper, A., \& Poulsen, E. (1995). Et princip - mange veje. Undervisningsdifferentiering. Engelsk, Fransk, Tysk. Kroghs forlag.

Graf, S.T. (2012). Læremidler og almendidaktiske modeller - en ny didaktisk strukturmodel. I S. T. Graf, T. I. Hansen, \& J. J. Hansen (red.), Læremidler i Didaktikken - Didaktikken i Læremidler, s. 89-114.

Graf, S.T., \& Carlsen, D. (2016). Elevfeedback og Elevbaro - Teknisk rapport fra lærersurvey $i$ Esbjerg kommune. Læremiddel.dk.

Graf, S. T., \& Carlsen, D. (2018). Undervisningsdifferentiering gennem digital elevfeedback. I: Bundsgaard, J., Georgsen, M., Graf, S. T., Hansen, T. I., \& Skott, C.K. (red.), Innovativ undervisning med it - Forskning i tre demonstrationsskoleforsøg II (s. 61-85). Århus Universitetsforlag.

Graf, S.T., \& Christensen, A.S. (2020). Muligheder og grænser for elevdemokrati på efterskoler. I: Graf, S.T., \& Jensen, U.H, (red.), Efterskolens praksis under lup - undersøgelser of dannende undervisning og samvær (s. 220-246). Klim.

Hansen, T.I., \& Bundsgaard, J. (2016). Effektmåling af demonstrationsskoleforsøg. Afrapportering af kvantitative undersøgelser på tværs af de tre demonstrationsskoleprojekter i AUUC-konsortiet. Læremiddel.dk.

Hansen, V.R., Horn, I., \& Robenhagen, O. (1992). Undervisningsdifferentiering 1 -idé og grundlag. Danmarks Pædagogiske Institut.

Harrit, O., Jansen, M., \& Kristensen, H.J. (1993). Undervisningsdifferentiering i skolen. Aktuelt belyst fra udviklingsarbejder i 1992. Undervisningsministeriet.

Klafki, W. (2001). Dannelsesteori og didaktik. Nye studier. Klim.

Krogh-Jespersen, K., \& Striib, A. (1993). En elev, eleven, flere elever, alle eleverne: om undervisningsdifferentiering (Vol. 1). Danmarks Lærerforening.

Langager, S. (2015). Undervisningsdifferentieringsprojektet - lærernes syn på sagen. I: Skibsted, E., Svendsen, H.B., Østergaard, K., \& Langager, S. (red.), Undervisningsdifferentiering : et princip møder praksis (s. 189-206). Akademisk Forlag. 
Lynggaard, K. (2010). Dokumentanalyse. I: Brinkmann, S., Tanggaard, L. (red.), Kvalitative metoder: en grundbog (s. 153-168). Hans Reitzel.

Ongstad, S. (2012). Morsmålsdidaktikk som fag og forskningsfelt i overnasjonalt perspektiv. I: Ongstad, S. (red.), Nordisk morsmålsdidaktikk. Forskning, felt og fag (s. 21-46). Novus AS.

Pettersson, M., Hansen, T.I., Kølsen Petersen, C., \& Bundsgaard, J. (2015). Læreres praksis. Data fra lærersurvey i AUUC-konsortiets demonstrationsskoleprojekter. Teknisk rapport. Læremiddel.dk.

Rousseau, J.J. (1762/1962). Emile eller om opdragelsen. Bind 1-3. Borgen.

Skibsted, E. (2015). En model for undervisningsdifferentiering - forståelse til handling. I: Skibsted, E., Svendsen, H.B., Østergaard, K., \& Langager, S. (red.), Undervisningsdifferentiering: et princip møder praksis (s. 31-47). Akademisk Forlag.

Skibsted, E., Svendsen, H.B., Østergaard, K., \& Langager, S. (red.) (2015). Undervisningsdifferentiering: et princip møder praksis. Akademisk forlag.

Tetler, S. (2015). Inklusion og undervisningsdifferentiering - baggrund og perspektiver. I: Skibsted, E., Svendsen, H.B., Østergaard, K., \& Langager, S. (red.), Undervisningsdifferentiering: et princip møder praksis (s. 17-30). Akademisk Forlag. 